\title{
Characterization of Physical, Spectroscopic and Thermal Properties of Biofield Treated Biphenyl
}

\author{
Mahendra Kumar Trivedi ${ }^{1}$, Rama Mohan Tallapragada ${ }^{1}$, Alice Branton ${ }^{1}$, Dahryn Trivedi ${ }^{1}$, \\ Gopal Nayak ${ }^{1}$, Rakesh Kumar Mishra ${ }^{2}$, Snehasis Jana ${ }^{2, *}$ \\ ${ }^{1}$ Trivedi Global Inc., Henderson, USA \\ ${ }^{2}$ Trivedi Science Research Laboratory Pvt. Ltd., Bhopal, Madhya Pradesh, India
}

\section{Email address:}

publication@trivedisrl.com (S. Jana)

\section{To cite this article:}

Mahendra Kumar Trivedi, Rama Mohan Tallapragada, Alice Branton, Dahryn Trivedi, Gopal Nayak, Rakesh Kumar Mishra, Snehasis Jana. Characterization of Physical, Spectroscopic and Thermal Properties of Biofield Treated Biphenyl. American Journal of Chemical Engineering. Vol. 3, No. 5, 2015, pp. 58-65. doi: 10.11648/j.ajche.20150305.11

\begin{abstract}
Biphenyl is used as an intermediate for synthesis of various pharmaceutical compounds. The objective of present research was to investigate the influence of biofield treatment on physical, spectroscopic and thermal properties of biphenyl. The study was performed in two groups (control and treated). The control group remained as untreated, and biofield treatment was given to treated group. The control and treated biphenyl were characterized by X-ray diffraction (XRD), differential scanning calorimetry (DSC), thermogravimetric analysis (TGA), Fourier transform infrared (FT-IR) spectroscopy, Ultravioletvisible (UV-Vis) spectroscopy and surface area analysis. The treated biphenyl showed decrease in intensity of XRD peaks as compared to control. Additionally, crystallite size was decreased in treated biphenyl by $16.82 \%$ with respect to control. The treated biphenyl $\left(72.66^{\circ} \mathrm{C}\right)$ showed increase in melting temperature as compared to control biphenyl $\left(70.52^{\circ} \mathrm{C}\right)$. However, the latent heat of fusion $(\Delta \mathrm{H})$ of treated biphenyl was substantially changed by $18.75 \%$ as compared to control. Additionally, the treated biphenyl $\left(155.14^{\circ} \mathrm{C}\right)$ showed alteration in maximum thermal decomposition temperature $\left(\mathrm{T}_{\max }\right)$ as compared to control sample $\left(160.97^{\circ} \mathrm{C}\right)$. This showed the alteration in thermal stability of treated biphenyl as compared to control. Spectroscopic analysis (FT-IR and UV-visible) showed no alteration in chemical nature of treated biphenyl with respect to control. Surface area analysis through Brunauer-Emmett-Teller analysis (BET) analyzer showed significant alteration in surface area as compared to control. Overall, the result demonstrated that biofield has substantially affected the physical and thermal nature of biphenyl.
\end{abstract}

Keywords: Biphenyl, X-ray Diffraction, Thermal Analysis, Fourier Transform Infrared Spectroscopy, Ultraviolet-Visible Spectroscopy

\section{Introduction}

Biphenyl is an organic compound occurs naturally in coal tar, crude oil and natural gas and it is mainly isolated from these sources by distillation process. It's a white crystalline compound with peculiar pleasant smell [1]. Biphenyl is mainly a neutral molecule however, it participates in a number of reactions similar like benzene such as substitution reaction upon treatment with halogens in the presence of Lewis acid. Biphenyl is an important compounds used as an intermediate for organic synthesis and they have insightful pharmacological activity. Biphenyl has been used for synthesis of wide range of compounds with diverse pharmaceutical applications [2] etc. For instance, biphenyl carboxylic benzimidazole derivative has excellent antihypertensive activity [3]. Additionally, biphenyl-4carboxylic acid 2-(aryl)-4-oxo-thiazolidin-3-yl-amide was designed and studied for its antimicrobial activity [4].

However, the biphenyl has low reactivity due to lack of functional groups [2] hence, it should be modified in order to improve its reaction kinetics. Recently Chaudhary et. al., showed that crystallite size reduction due to ball milling may have significant influence on improving reaction kinetics [5]. The other strategies were grain size reduction and catalyst addition [6-10]. Recently biofield treatment was used as a potential strategy to modify the physical and thermal properties of various metals. Hence, authors are keen to investigate the influence of biofield treatment on biphenyl in 
order to modulate its physical and thermal properties that can improve its reactivity.

Researchers have experimentally demonstrated the presence of electromagnetic field around the human body using medical technologies such as electromyography, electrocardiography and electroencephalogram [11]. Additionally, it was shown that bioelectricity generated from heart, brain functions or due to the motion of charged particles such as protons, electrons, and ions in the human body [12]. Thus, the human body emits the electromagnetic waves in form of bio-photons, which surrounds the body, which is commonly known as biofield. Therefore, a human has the ability to harness the energy from environment/Universe and can transmit into any object (living or non-living) around the Globe. The object(s) always receive the energy and respond into useful way that is called biofield energy and this process is known as biofield treatment.

Mr. Trivedi's biofield treatment is known to alter the characteristics of many things in various research fields such as, material science [13-15], agriculture [16-18] and biotechnology [19]. Biofield treatment has shown excellent results in improving the antimicrobial susceptibility pattern, and alteration of biochemical reactions, as well as induced alterations in characteristics of pathogenic microbes [20-22]. Exposure to biofield treatment caused paramount increase in medicinal property, growth, and anatomical characteristics of ashwagandha [23].

By considering the above-mentioned excellent results outcome from biofield treatment and pharmaceutical significance of biphenyl, this study was undertaken to investigate the impact of biofield on physicochemical properties of these compounds.

\section{Materials and Methods}

Biphenyl was procured from Loba Chemie Ltd., India. The sample was divided into two parts; one was kept as a control sample, and another was coded as treated sample. The treatment group was in sealed pack and handed over to Mr. Trivedi for biofield treatment under laboratory condition. Mr. Trivedi provided the treatment through his energy transmission process to the treated group without touching the sample. The control and treated samples were characterized by XRD, DSC, TGA, FT-IR, UV-visible spectroscopy and surface area analysis.

\subsection{X-ray Diffraction (XRD) Study}

XRD analysis of biphenyl was carried out on Phillips, Holland PW 1710 X-ray diffractometer system, which had a copper anode with nickel filter. The radiation of wavelength used by the XRD system was $1.54056 \AA$. The data obtained from this XRD were in the form of a chart of $2 \theta$ vs. intensity and a detailed table containing peak intensity counts, $d$ value $(\AA)$, peak width $\left(\theta^{0}\right)$, relative intensity (\%) etc. The crystallite size $(\mathrm{G})$ was calculated by using formula:

$$
\mathrm{G}=\mathrm{k} \lambda /(\mathrm{b} \operatorname{Cos} \theta)
$$

Percent change $(\%)$ in crystallite size $=\left[\left(\mathrm{G}_{\mathrm{t}}-\mathrm{G}_{\mathrm{c}}\right) / \mathrm{G}_{\mathrm{c}}\right] \times 100$

Where, $G_{c}$ and $G_{t}$ are crystallite size of control and treated powder samples respectively.

\subsection{Differential Scanning Calorimetry (DSC) Study}

The control and treated biphenyl were analyzed by using a Pyris-6 Perkin Elmer DSC on a heating rate of $10^{\circ} \mathrm{C} / \mathrm{min}$ under air atmosphere and air was flushed at a flow rate of 5 $\mathrm{mL} / \mathrm{min}$.

Percent change in melting point was calculated using following equations:

$\%$ change in Melting point $=\frac{\left[\mathrm{T}_{\text {Treated }}-\mathrm{T}_{\text {Control }}\right]}{\mathrm{T}_{\text {Control }}} \times 100$

Where, $\mathrm{T}_{\text {Control }}$ and $\mathrm{T}_{\text {Treated }}$ are the melting point of control and treated samples, respectively.

Percent change in latent heat of fusion was calculated using following equations:

$\%$ change in Latent heat of fusion

$$
=\frac{\left[\Delta \mathrm{H}_{\text {Treated }}-\Delta \mathrm{H}_{\text {Control }}\right]}{\Delta \mathrm{H}_{\text {Control }}} \times 100
$$

Where, $\Delta \mathrm{H}_{\text {Control }}$ and $\Delta \mathrm{H}_{\text {Treated }}$ are the latent heat of fusion of control and treated samples, respectively.

\subsection{Thermogravimetric Analysis-Differential Thermal Analysis (TGA-DTA)}

Thermal stability of control and treated biphenyl were analyzed by using Mettler Toledo simultaneous TGA and differential thermal analyzer (DTA). The samples were heated from room temperature to $400^{\circ} \mathrm{C}$ with a heating rate of $5^{\circ} \mathrm{C} / \mathrm{min}$ under air atmosphere.

Percent change in temperature at which maximum weight loss occur in sample was calculated using following equation:

$\%$ change in $T_{\max }=\left[\left(T_{\max , \text { treated }}-\mathrm{T}_{\max , \text { control }}\right) / \max\right.$, control $] \times 100$

Where, $\mathrm{T}_{\max \text {, control }}$ and $\mathrm{T}_{\max }$, treated are the maximum thermal decomposition temperature in control and treated sample, respectively.

\subsection{FT-IR Spectroscopy}

FT-IR spectra were recorded on Shimadzu's Fourier transform infrared spectrometer (Japan) with frequency range of $4000-500 \mathrm{~cm}^{-1}$. The treated sample was divided in two parts T1 and T2 for FT-IR analysis.

\subsection{UV-Vis Spectroscopic Analysis}

UV spectra of control and treated biphenyl were recorded on Shimadzu UV-2400 PC series spectrophotometer with $1 \mathrm{~cm}$ quartz cell and a slit width of $2.0 \mathrm{~nm}$. The analysis was carried out using wavelength in the range of $200-400 \mathrm{~nm}$. The treated 
sample was divided in two parts T1 and T2 for the analysis.

\subsection{Surface Area Analysis}

Surface area of control and treated biphenyl were characterized by surface area analyzer, SMART SORB 90 Brunauer-Emmett-Teller (BET) using ASTM D 5604 method which had a detection range of $0.2-1000 \mathrm{~m}^{2} / \mathrm{g}$. Percent changes in surface area were calculated using following equation:

$$
\% \text { change in surface area }=\frac{\left[S_{\text {Treated }}-S_{\text {Control }}\right]}{S_{\text {Control }}} \times 100
$$

Where, $\mathrm{S}_{\text {Control }}$ and $\mathrm{S}_{\text {Treated }}$ are the surface area of control and treated samples respectively.

\section{Results and Discussion}

\subsection{XRD Study}

XRD diffractogram of control and treated biphenyl are shown in Figure 1. The XRD graph of control showed peaks at $2 \theta$ equals to $18.62^{\circ}, 18.89^{\circ}, 20.44^{\circ}, 20.70^{\circ}, 21.58^{\circ}, 22.73^{\circ}$, $22.97^{\circ}, 27.79^{\circ}, 28.12^{\circ}, 37.52^{\circ}, 37.81^{\circ}$, and $47.81^{\circ}$. However, the treated biphenyl showed decrease in intensity of the XRD peaks. The XRD peaks were observed at $2 \theta$ equals to $18.20^{\circ}$, $18.35^{\circ}, 18.55^{\circ}, 20.45^{\circ}, 22.62^{\circ}, 22.76^{\circ}$, and $37.44^{\circ}$. The decrease in intensity of XRD peaks in treated biphenyl was due to decrease in crystallinity of the sample. The crystallite size of control biphenyl was $88.06 \mathrm{~nm}$; however, it was decreased to $79.22 \mathrm{~nm}$ in the corresponding treated sample (Figure 2). Thus the crystallite size was decreased by $10.04 \%$ in treated biphenyl as compared to control. It was previously suggested that increase in internal micro strain may decrease the corresponding crystallite size of the material [24]. Zhang et. al., showed that presence of strain and increase atomic displacement from their ideal lattice positions cause reduction in crystallite size [25]. Hence, it is assumed that biofield treatment may induce increase in internal strain and decrease in crystallite size of the biphenyl as compared to control. It was previously suggested that nano scale particle size and small crystallite size can overcome slow diffusion rate by reducing overall diffusion distance and this enhances the net reaction rate $[26,27]$. Hence, it is assumed that lower crystallite size of treated biphenyl may improve its reaction rate [5] and it could be utilized for synthesis of pharmaceutical compounds.
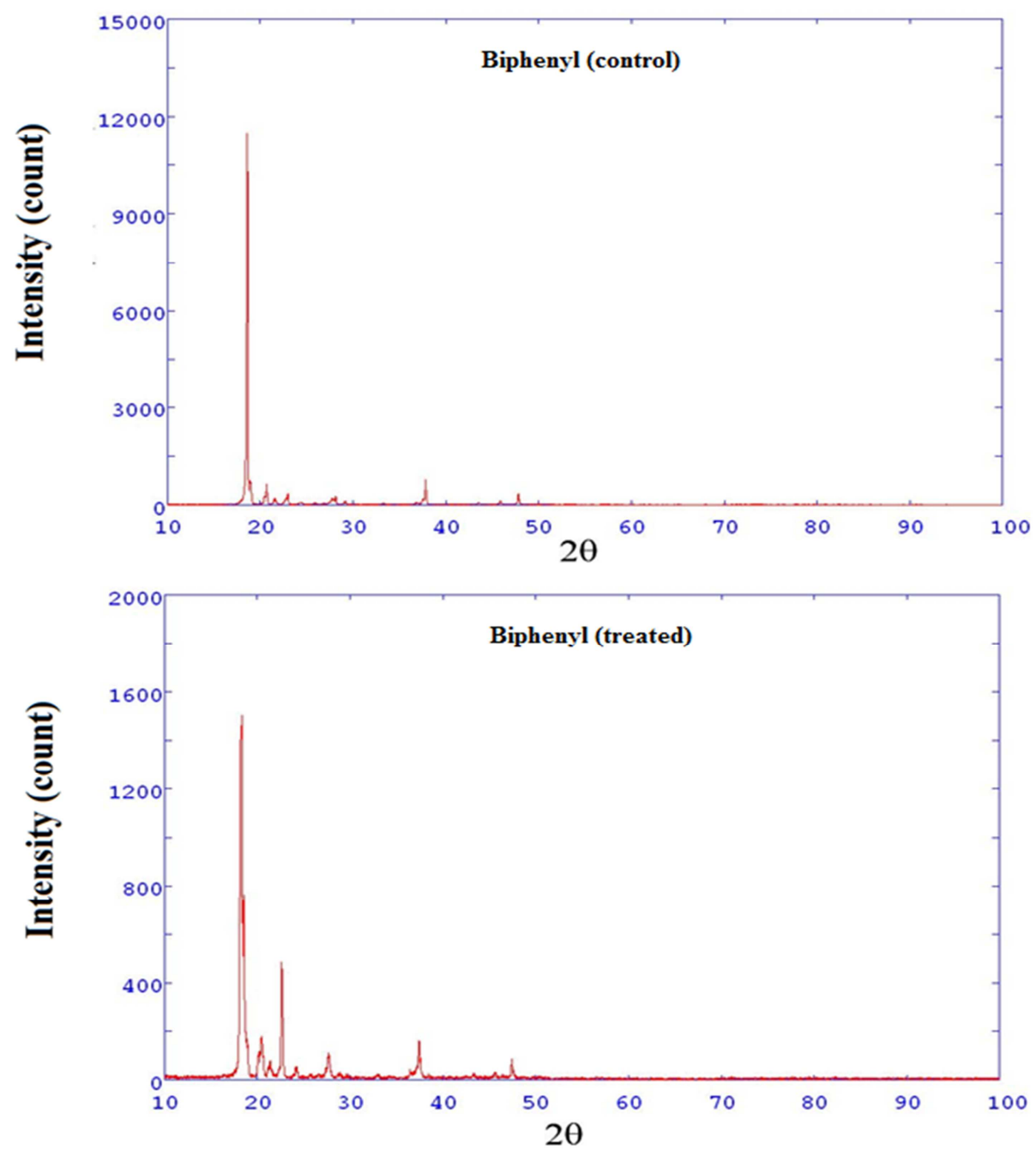

Figure 1. XRD difractograms of control and treated biphenyl. 


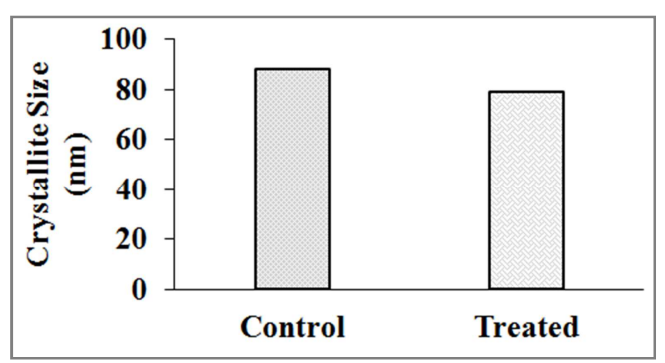

Figure 2. Crystallite size of control and treated biphenyl.

\subsection{DSC Study}

DSC was used to investigate the melting temperature and latent heat of fusion of control and treated biphenyl and results are presented in Table 1 . The DSC of control biphenyl has a melting temperature at $70.52^{\circ} \mathrm{C}$. Contrarily, treated biphenyl showed a melting temperature at $72.66^{\circ} \mathrm{C}$. The result showed the increase in melting temperature which may be due to change in kinetic energy of the treated biphenyl as compared to control. The treated biphenyl showed increased in melting temperature by $3.03 \%$ as compared to control. However, the treated biphenyl $(94.06 \mathrm{~J} / \mathrm{g})$ showed (Table 1) a decrease in latent heat of fusion $(\Delta \mathrm{H})$ with respect to control $(115.77 \mathrm{~J} / \mathrm{g})$. Thus result showed decrease in latent heat of fusion of treated biphenyl by $18.75 \%$ in comparison with control (Table 1). It is assumed that treated biphenyl may already present in high-energy state prior to melting. Previously our group has reported that biofield treatment has changed the latent heat of fusion of lead and tin powders [13]. Hence, it is assumed that biofield treatment might alter the potential energy of treated biphenyl atoms that led to change in latent heat of fusion.

Table 1. DSC data of control and treated biphenyl.

\begin{tabular}{lllllll}
\hline Sample & $\operatorname{Tm}\left({ }^{\circ} \mathbf{C} ;\right.$ control $)$ & Tm $\left({ }^{\circ} \mathbf{C} ;\right.$ treated $)$ & \% Change in $\mathbf{T m}\left({ }^{\circ} \mathbf{C}\right)$ & Control $(\Delta \mathbf{H} ; \mathbf{J} / \mathbf{g})$ & Treated $(\Delta \mathbf{H} ; \mathbf{J} / \mathbf{g})$ & $\%$ Change in $\Delta \mathbf{H}$ \\
\hline Biphenyl & 70.52 & 72.66 & 3.03 & 115.77 & -18.75 & -94.06 \\
\hline
\end{tabular}

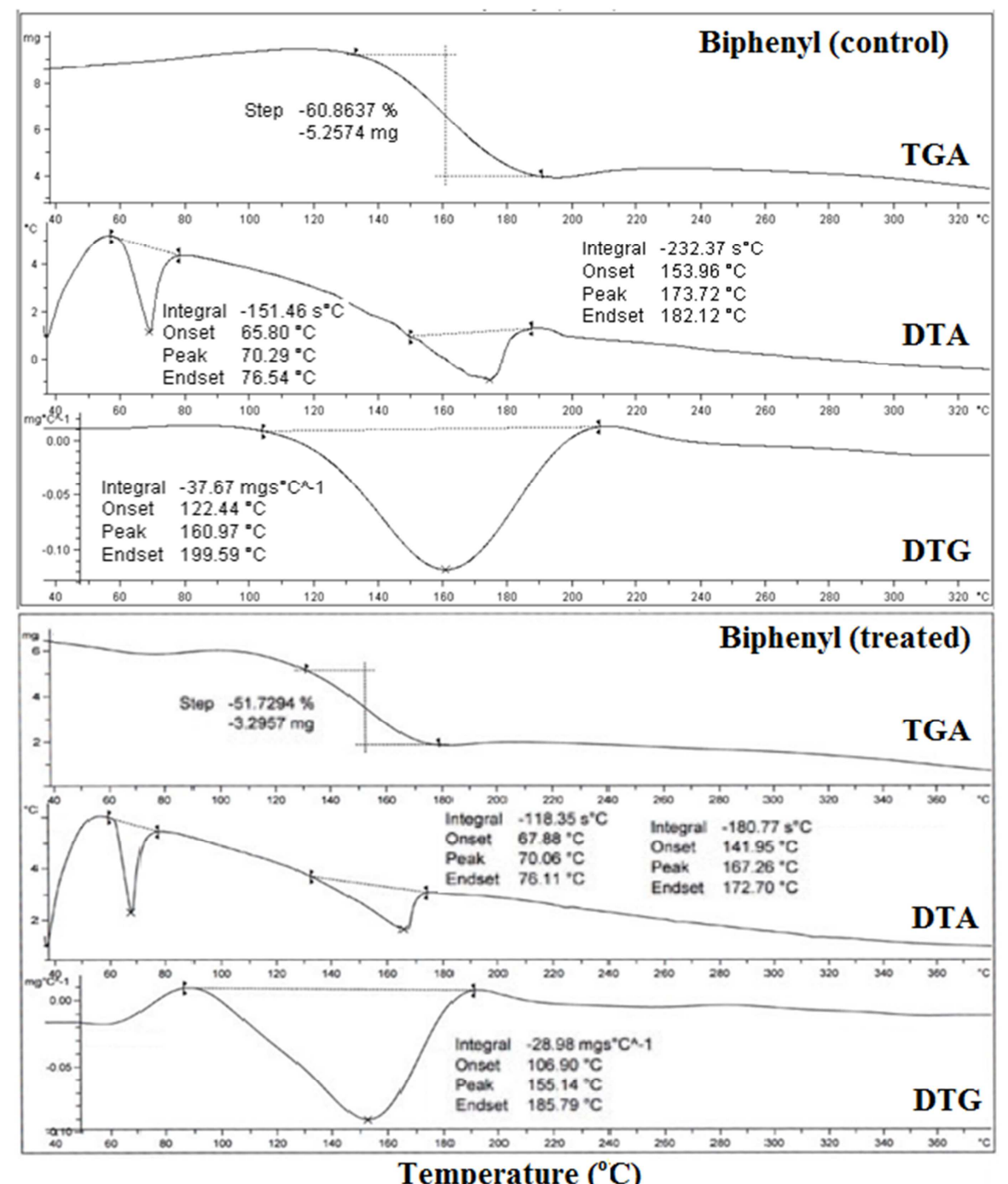

Figure 3. TGA thermogram of control and treated biphenyl. 


\subsection{TGA Analysis}

TGA thermogram of control and treated biphenyl are presented in Figure 3. The thermal degradation of control biphenyl started at around $134^{\circ} \mathrm{C}$ and the degradation terminated at around $192^{\circ} \mathrm{C}$. The sample rapidly lost $60.86 \%$ of its weight. However, the thermal degradation of treated biphenyl started at around $131^{\circ} \mathrm{C}$ and stopped at around $179^{\circ} \mathrm{C}$. During this thermal event the sample lost $51.73 \%$ of its total weight. DTA thermogram of biphenyl is shown in Figure 3. The DTA of control sample exhibited two endothermic peaks at $70.29^{\circ} \mathrm{C}$ and $173.72^{\circ} \mathrm{C}$ respectively. The former peak represented to melting of the sample and latter peak is due to thermal decomposition of the sample. DTA of treated biphenyl also showed two endothermic at $70.06^{\circ} \mathrm{C}$ and $167.26^{\circ} \mathrm{C}$. The first peak was due to melting and second was attributed to decomposition of the sample. DTG thermogram of control biphenyl showed (Table 1) $\mathrm{T}_{\max }$ value at $160.97^{\circ} \mathrm{C}$; however, the treated biphenyl showed decrease in $\mathrm{T}_{\max }$ value $\left(155.14^{\circ} \mathrm{C}\right)$. The decrease in $\mathrm{T}_{\max }$ of treated biphenyl by $3.62 \%$ may be correlated to reduced thermal stability after biofield treatment.

\subsection{FT-IR Spectroscopy}

FT-IR spectra of control and treated biphenyl are presented in Figure 4. The typical FT-IR spectrum of control biphenyl showed aromatic methyl group stretching peaks at 2926, 3034 and $3063 \mathrm{~cm}^{-1}$. C-C stretch in phenyl ring was observed at $1570 \mathrm{~cm}^{-1}$. The peaks at 1041 and $1076 \mathrm{~cm}^{-1}$ were due to in plane $\mathrm{C}-\mathrm{H}$ bending vibrations. The peaks at 698,729 , and $781 \mathrm{~cm}^{-1}$ were mainly due aromatic out of plane $\mathrm{C}-\mathrm{H}$ bending vibrations [28].

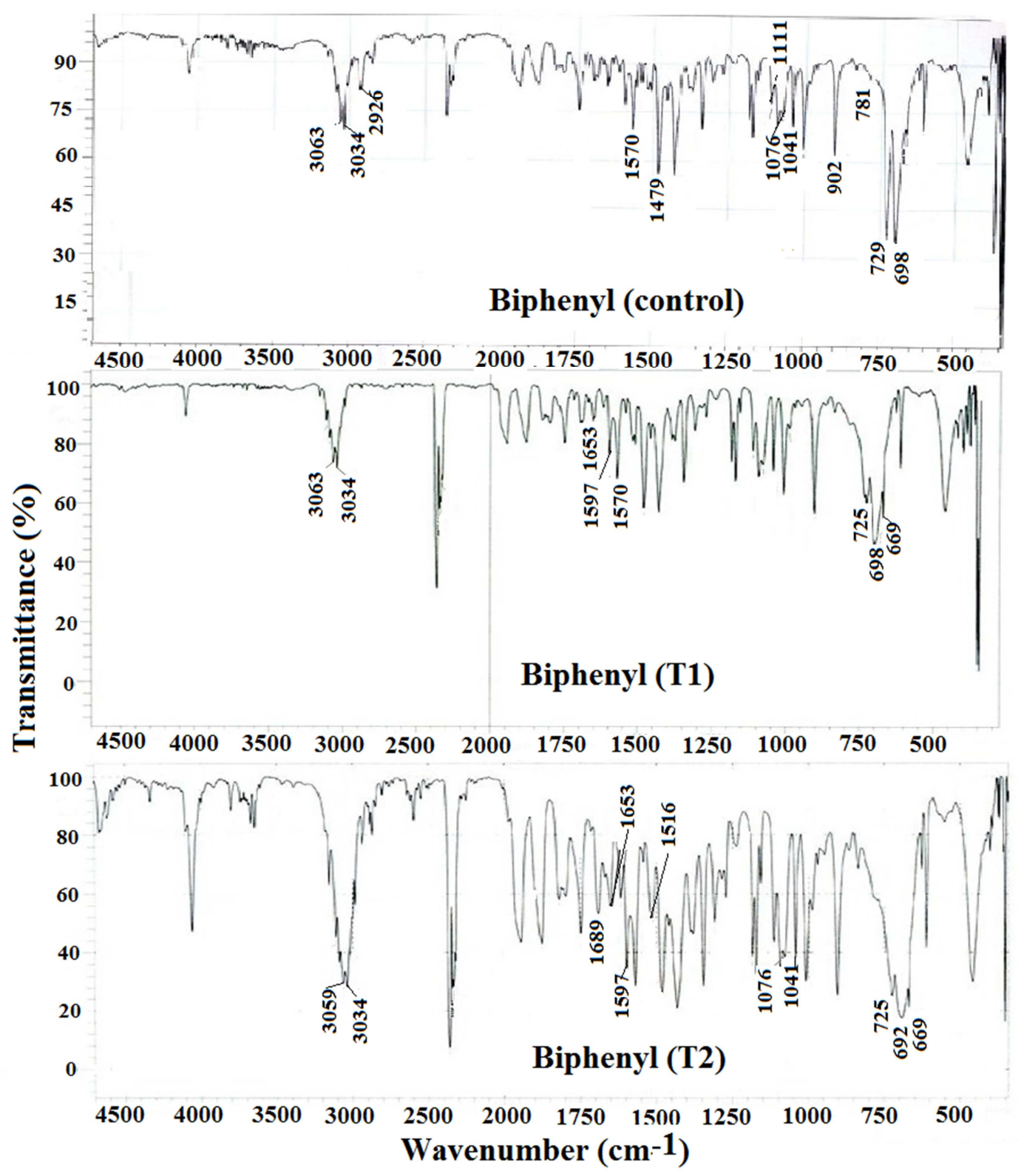

Figure 4. FTIR spectra of control and treated biphenyl (T1 and T2). 
Whereas, the FT-IR of treated biphenyl (T1) compound showed peaks at 3034 and $3063 \mathrm{~cm}^{-1}$ were mainly due to aromatic $\mathrm{C}-\mathrm{H}$ stretching vibrations. C-C stretching vibrations in the phenyl ring were observed at 1570 and $1597 \mathrm{~cm}^{-1}$. The spectrum showed strong peak at $1653 \mathrm{~cm}^{-1}$ that was mainly due to aromatic $\mathrm{C}=\mathrm{C}$ bending vibrations. The aromatic $\mathrm{C}-\mathrm{H}$ bending vibration peaks were appeared at 669,698 , and 725 $\mathrm{cm}^{-1}$.

FT-IR spectrum of treated biphenyl (T2) is shown in Figure 4. The FT-IR spectrum showed intense peaks at 3034 and $3059 \mathrm{~cm}^{-1}$ which were due to aromatic C-H stretching vibrations. The stretching peaks at $1516-1597 \mathrm{~cm}^{-1}$ were mainly due $\mathrm{C}-\mathrm{C}$ bond in the phenyl ring. Aromatic $\mathrm{C}=\mathrm{C}$ bending peaks were observed at $1653-1689 \mathrm{~cm}^{-1}$. Other peaks were observed at 1041 , and 1076 were due to aromatic $\mathrm{C}-\mathrm{H}$ bending in the T2 sample. The FT-IR results of treated biphenyl (T1 and T2) showed no change in frequency of the absorption peaks as compared to control. This indicated that
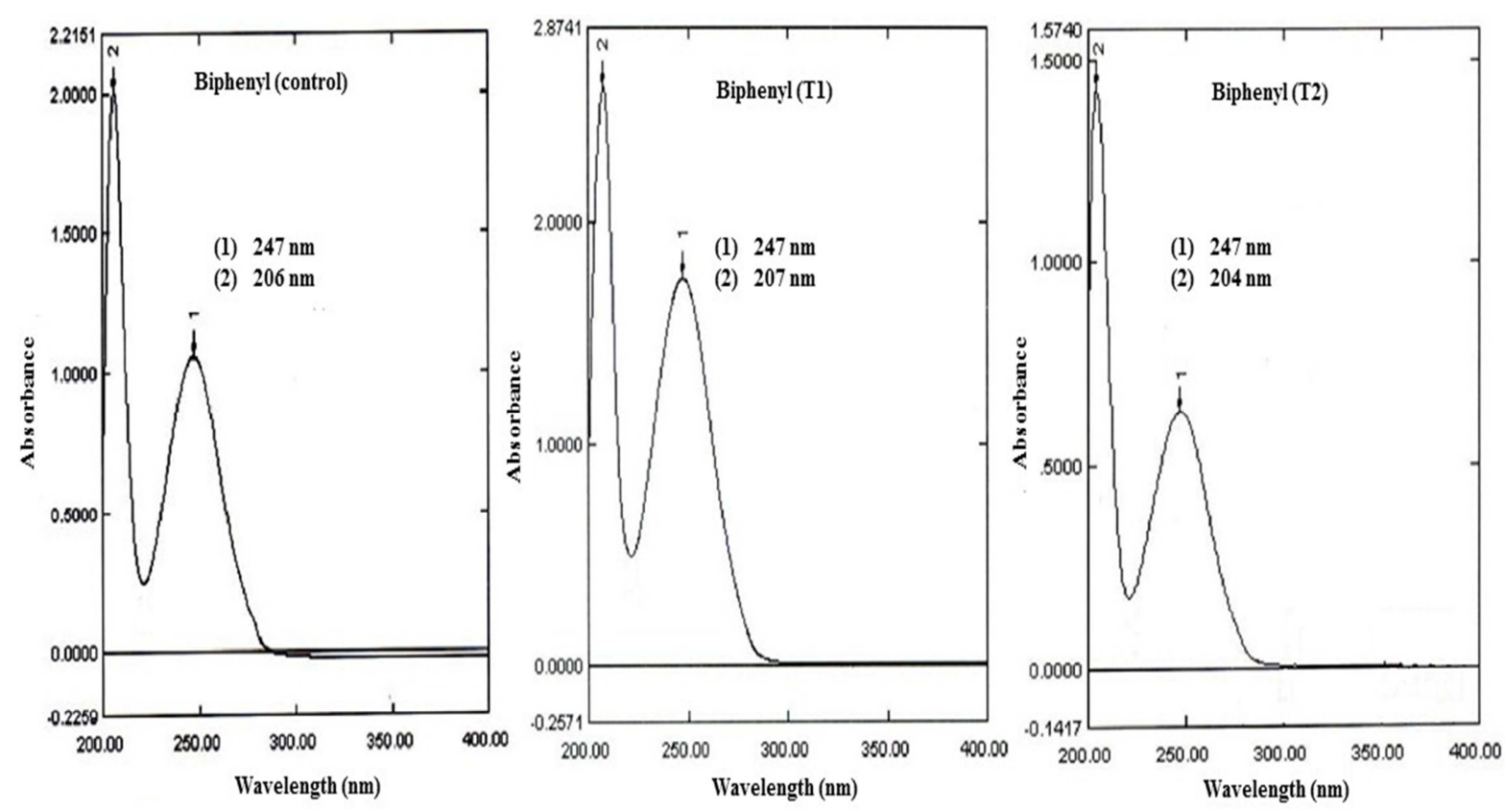

Figure 5. UV visible spectra of control and treated (T1 and T2) biphenyl.

\subsection{Surface Area Analysis}

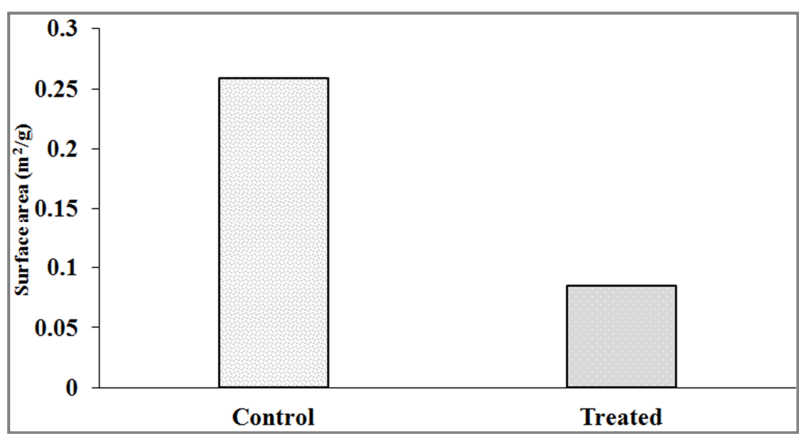

Figure 6. Surface area of control and treated biphenyl.

Surface area of control and treated biphenyl are presented in Figure 6. The surface area of control biphenyl was 0.2592 biofield treatment has no significant effect on altering the structure of biphenyl.

\subsection{UV-visible Spectroscopy}

UV-visible spectra of control and treated biphenyl (T1 and T2) are presented in Figure 5. The UV of control biphenyl showed two absorption peaks at 247 and $206 \mathrm{~nm}\left(\lambda_{\max }\right)$. However, the treated biphenyl (T1) showed absorption peaks at 247 and $207 \mathrm{~nm}$. Similarly, the biphenyl (T2) showed presence of absorption peaks at 247 and $204 \mathrm{~nm}$. The result showed no change in chromophoric group of the treated biphenyl (T1 and T2) as compared to control sample. Therefore, it is suggested that the biofield treatment did not disturb the energy gap between HOMO-LUMO [29] in treated sample, and it was found similar to the control sample. 
size. DSC of treated biphenyl showed an increase in melting temperature by $3.03 \%$ with respect to control. Nevertheless, the treated biphenyl showed substantial change $(18.75 \%)$ in latent heat of fusion with respect to control. However, TGA showed alteration in thermal stability of the treated biphenyl with respect to control. The spectroscopic analysis using FTIR and UV analysis showed no changes in the chemical nature of treated biphenyl as compared to control. BET analysis showed alteration in surface area in treated biphenyl with respect to control. The lower crystallite size of biofield treated biphenyl could improve the rate of reaction and this may improve the reaction yield. Hence, it is assumed that biofield treated biphenyl could be used as effective intermediate for synthesis of pharmaceutical compounds.

\section{Abbreviations}

\author{
XRD: X-ray diffraction; \\ DSC: Differential scanning calorimetry; \\ TGA: Thermogravimetric analysis; \\ DTA: Differential thermal analyzer; \\ DTG: Derivative thermogravimetry; \\ UV-Vis: Ultraviolet-visible; \\ BET:Brunauer-Emmett Teller analysis
}

\section{Acknowledgement}

The authors would like to thank all the laboratory staff of MGV Pharmacy College, Nashik for their assistance during the various instrument characterizations.

\section{References}

[1] Pagan A (2012) http://mustang.millersville.edu/ iannone/research/Pagan07.pd $\mathrm{f}$ (accessed 30.05.12).

[2] Jain ZJ, Gide PS, Kankate RS (2013) Biphenyls and their derivatives as synthetically and pharmacologically important aromatic structural moieties. Arab J Chem (In Press).

[3] Kumar JR, Jawahar J, Pathak DP (2006) Synthesis of benzimidazole derivatives: As anti-hypertensive agents. E J Chem 3: 278-285.

[4] Madhukar A, Kannappan N, Deep A, Kumar P, Kumar M, et al. (2009) Synthesis and antimicrobial studies of biphenyl-4carboxylic acid 2-(Aryl)-4-oxo-thiazolidin-3-yl-amide. Int $\mathbf{J}$ Chem Tech Res 1: 1376-1380.

[5] Chaudhary AL, Sheppard DA, Paskevicius M, Pistidda, C, Dornheim M, et al. (2015) Reaction kinetic behaviour with relation to crystallite/grain size dependency in the $\mathrm{Mg}-\mathrm{Si}-\mathrm{H}$ system. Acta Mater 95: 244-253.

[6] Huot J, Liang G, Boily S, Van Neste A, Schulz R (1999) Structural study and hydrogen sorption kinetics of ball-milled magnesium hydride. J Alloys Compd 293-295: 495-500.

[7] Gross KJ, Spatz P, Zuttel A, Schlapbach L (1996) Mechanically milled Mg composites for hydrogen storage the transition to a steady state composition. J Alloys Compd 240:
206-213.

[8] Gerasimov KB, Konstanchuck IG, Chizhik SA, Bobet JL (2009) "Hysteresis" in interaction of nanocrystalline magnesium with hydrogen. Int J Hydrogen Energ 34: 19161921.

[9] Hanada N, Ichikawa T, Orimo SI, Fujii H (2004) Correlation between hydrogen storage properties and structural characteristics in mechanically milled magnesium hydride $\mathrm{MgH}_{2}$, J Alloys Compd 366: 269-273.

[10] Wronski Z, Varin RA, Chiu C, Czujko T, Calka A (2007) Mechanochemical synthesis of nanostructured chemical hydrides in hydrogen alloying mills. J Alloys Compd 434 435: 743-746.

[11] Zahra M, Farsi M (2009) Biofield therapies: Biophysical basis and biological regulations. Complement Ther Clin Pract 15: 35-37.

[12] Neuman MR (2000) Biopotential electrodes. The biomedical engg handbook: (2ndedn), Boca Raton: CRC Press LLC.

[13] Trivedi MK, Patil S, Tallapragada RM (2013) Effect of biofield treatment on the physical and thermal characteristics of vanadium pentoxide powders. J Material Sci Eng S11: 001.

[14] Trivedi MK, Patil S, Tallapragada RM (2013) Effect of biofield treatment on the physical and thermal characteristics of silicon, tin and lead powders. J Material Sci Eng 2: 125.

[15] Trivedi MK, Patil S, Tallapragada RMR (2015) Effect of biofield treatment on the physical and thermal characteristics of aluminium powders. Ind Eng Manag 4: 151.

[16] Shinde V, Sances F, Patil S, Spence A (2012) Impact of biofield treatment on growth and yield of lettuce and tomato. Aust J Basic Appl Sci 6: 100-105.

[17] Sances F, Flora E, Patil S, Spence A, Shinde V (2013) Impact of biofield treatment on ginseng and organic blueberry yield. Agrivita J Agric Sci 35: 22-29.

[18] Lenssen AW (2013) Biofield and fungicide seed treatment influences on soybean productivity, seed quality and weed community. Agricultural Journal 8: 138-143.

[19] Patil SA, Nayak GB, Barve SS, Tembe RP, Khan RR (2012) Impact of biofield treatment on growth and anatomical characteristics of Pogostemon cablin (Benth.). Biotechnology 11: $154-162$.

[20] Trivedi MK, Patil S (2008) Impact of an external energy on Staphylococcus epidermis [ATCC-13518] in relation to antibiotic susceptibility and biochemical reactions - An experimental study. J Accord Integr Med 4: 230-235.

[21] Trivedi MK, Patil S (2008) Impact of an external energy on Yersinia enterocolitica [ATCC-23715] in relation to antibiotic susceptibility and biochemical reactions: An experimental study. Internet J Alternative Med 6: 2.

[22] Trivedi MK, Bhardwaj Y, Patil S, Shettigar H, Bulbule A (2009) Impact of an external energy on Enterococcus faecalis [ATCC-51299] in relation to antibiotic susceptibility and biochemical reactions - An experimental study. J Accord Integr Med 5: 119-130.

[23] Altekar N, Nayak G (2015) Effect of biofield treatment on plant growth and adaptation. J Environ Health Sci 1: 1-9. 
[24] Paiva-Santos CO, Gouveia H, Las WC, Varela JA (1999) Gauss-lorentz size-strain broadening and cell parameters analysis of $\mathrm{Mn}$ doped $\mathrm{SnO}_{2}$ prepared by organic route. Materials Structure 6: 111-115.

[25] Zhang K, Alexandrov IV, Kilmametov AR, Valiev RZ, Lu K (1997) The crystallite-size dependence of structural parameters in pure ultrafine-grained copper. J Phys D Appl Phys 30: 3008-3015.

[26] Chaudhary AL, Sheppard DA, Paskevicius M, Webb CJ, Gray $\mathrm{EM}$, et al. (2014) $\mathrm{Mg}_{2} \mathrm{Si}$ nanoparticle synthesis for high pressure hydrogenation. J Phys Chem C 118: 1240-1247.

[27] Chaudhary AL, Sheppard DA, Paskevicius M, Saunders M, Buckley C (2014) Mechanochemical synthesis of amorphous silicon nanoparticles. R Soc Chem Adv 42: 21979-21983.

[28] Karabacak M, Yilan E (2012) Molecular structure, spectroscopic (FT-IR, FT-Raman, ${ }^{13} \mathrm{C}$ and ${ }^{1} \mathrm{H}$ NMR, UV), polarizability and first-order hyperpolarizability, HOMO and LUMO analysis of 4-methylbiphenyl-2-carbonitrile. Spectrochim Acta A Mol Biomol Spectrosc 87: 273-285.

[29] Pavia DL, Lampman GM, Kriz GS (2001) Introduction to spectroscopy. (3rdedn), Thomson Learning, Singapore.

[30] Mennucci B, Martinez JM (2005) How to model solvation of peptides? Insights from a quantum-mechanical and molecular dynamics study of N-methylacetamide. I. Geometries, infrared, and ultraviolet spectra in water. J Phys Chem B 109: 9818-9829.

[31] Bendz D, Tuchsen PL, Christensen TH (2007) The dissolution kinetics of major elements in municipal solid waste incineration bottom ash particles. J Contam Hydrol 94: 178194. 